\title{
Uptake of urea by estuarine bacteria
}

\author{
Niels O. G. Jørgensen* \\ Department of Ecology, Royal Veterinary and Agricultural University, Thorvaldsensvej 40, 1871 Frederiksberg C, Denmark
}

\begin{abstract}
Uptake of urea was studied in batch cultures of natural bacterial assemblages or in GF/C filtered water from 4 estuarine sites, and was related to utilization of other $\mathrm{N}$ compounds and the total bacterial N production. During spring in Roskilde Fjord, Denmark, urea uptake varied 100fold and sustained 0.6 to $44 \%$ of the bacterial $\mathrm{N}$ demand, while uptake of dissolved free amino acids (DFAA) met 12 to $53 \%$ of the $\mathrm{N}$ demand. Enrichment with $\mathrm{NH}_{4}{ }^{+}$and DFAA reduced the urea uptake by up to 2.8-fold, demonstrating a higher preference for $\mathrm{NH}_{4}{ }^{+}$and DFAA than urea. In Knebel Vig, Denmark, bacterial uptake of urea varied significantly during a 9 d provoked algal bloom (mesocosms enriched with N, P, or Si). At Day 1, uptake of urea and DFAA was similar, but during development of a diatom bloom, bacterial urea uptake either increased 7 -fold (Day 5) or was insignificant (Day 9). In contrast, urea uptake in the control mesocosms remained unchanged. Urea uptake by the bacterial assemblages was on average 1.6-fold higher than the in situ (bacteria and algae) dark uptake, which again was 16 -fold lower than the in situ light uptake. Urea sustained 0.2 to $30 \%$ (nutrient-enriched mesocosms) and 9 to $41 \%$ (control) of the bacterial $\mathrm{N}$ demand, but $\mathrm{NH}_{4}{ }^{+}, \mathrm{NO}_{3}{ }^{-}$and DFAA were more important $\mathrm{N}$ sources. Bacterial preference for urea or $\mathrm{NH}_{4}{ }^{+}$alone, or in combination with glucose, was examined in the Limfjorden estuary, Denmark. Relative to controls, a 2-fold higher biomass was produced whether $\mathrm{NH}_{4}{ }^{+}$or urea was the $\mathrm{N}$ source, but urea sustained $<30 \%$ of the $\mathrm{N}$ biomass production and was less important than the ambient DFAA pool. In contrast to the Limfjorden studies, when enriched with glucose, bacteria in Santa Rosa Sound, Florida, USA, produced a lower biomass with urea than with $\mathrm{NH}_{4}{ }^{+}$. Enrichment with urea stimulated the DFAA assimilation, peptidase activity and utilization of $\mathrm{NO}_{3}{ }^{-}$, and urea made up $<50 \%$ of the $\mathrm{N}$ incorporation. The studies demonstrate that urea uptake rates by estuarine bacteria are variable and often unpredictable. Uptake of urea will typically be lower than of $\mathrm{NH}_{4}{ }^{+}$and DFAA, but occasionally, urea uptake can be of importance similar to $\mathrm{NH}_{4}{ }^{+}$and DFAA.
\end{abstract}

KEY WORDS: Urea $\cdot$ Bacterial uptake $\cdot$ DFAA $\cdot$ Ammonium-Bacterial N budgets Resale or republication not permitted without written consent of the publisher

\section{INTRODUCTION}

Urea is a nitrogenous waste product being excreted by many aquatic organisms, including zooplankton, mollusks, fish and mammals (Antia et al. 1991, Conover \& Gustavson 1999). In addition, bacteria produce urea during degradation of purines and other nitrogen (N) compounds such as arginine and allantoin (Vogels \& van der Drift 1976). The quantitative significance of microbial urea production in pelagic waters is unknown, but it has been suggested that urea production by bacteria on sinking particles can be involved in $\mathrm{N}$ cycling by providing ammonium for nitrification (Cho et al. 1996). A high urea production has been observed in undisturbed and nutrient-enriched marine sediments (Lomstein et al. 1989, Therkildsen \& Lom- stein 1994), and most likely reflects microbial degradation of organic matter rather than release by higher organisms (Pedersen et al. 1993).

Concentrations of urea have been found to vary from below $0.2 \mu \mathrm{M}$ in oceanic waters to about $2.5 \mu \mathrm{M}$ in estuarine and freshwater sites, and comprise from 0.5 to $>10 \%$ of the total pool of dissolved organic N (DON) (Bronk 2002). Higher urea concentrations (up to $12 \mu \mathrm{M}$ ) have been measured in running waters receiving run-off from agricultural areas where urea or manure is applied as fertilizer (Glibert et al. 2005). Hence, the urea pool appears to constitute a relatively large source of low-molecular and labile $\mathrm{N}$.

Urea can be an important $\mathrm{N}$ source to aquatic microorganisms, especially phytoplankton (Berman \& Bronk 2003). In estuarine and coastal waters, urea may 
sustain from 20 to $60 \%$ of the algal $\mathrm{N}$ demand (Sahlsten et al. 1988, Glibert et al. 1995). Less attention has been paid to urea as bacterial N source, although bacterial urea uptake unintentionally has been included in studies of $\left[{ }^{15}\right] \mathrm{N}$-urea uptake by phytoplankton due to the filter size (typically about $1.0 \mu \mathrm{m}$ ) used for collection of the $\left[{ }^{15}\right] \mathrm{N}$-labeled phytoplankton, e.g. by Lomas et al. (2002). In most studies on bacterial $\mathrm{N}$ cycling, dissolved free amino acids (DFAA) and $\mathrm{NH}_{4}{ }^{+}$have been considered as the major $\mathrm{N}$ sources to bacteria (Fuhrman 1990, Keil \& Kirchman 1991). Attempts to measure urea uptake by bacterioplankton in short-term studies ( 2 to $8 \mathrm{~h}$ ) have either been unsuccessful (open marine waters; Wheeler \& Kirchman 1986), or have shown a minor uptake $(<3 \%$ of the total bacterial $\mathrm{N}$ uptake in the Thames estuary; Middelburg \& Nieuwenhuize 2000). In contrast, in long-term batch cultures $(>3 \mathrm{~d}$ ) of freshwater and marine bacteria, a sizable uptake of urea has been measured in several cases (Jørgensen et al. 1998, 1999b, Middelboe et al. 1998).

Utilization of urea $\mathrm{N}$ by algae and bacteria requires splitting of urea by the enzyme urease. In bacteria, activity of the urease enzyme appears to be controlled by at least 2 different mechanisms. In Klebsiella aerogenes, synthesis of urease is initiated at low concentrations of 'high quality' $\mathrm{N}$ such as $\mathrm{NH}_{4}{ }^{+}$and amino acids (Friedrich \& Magasanik 1977). Since $\mathrm{NH}_{4}{ }^{+}$(from direct uptake or deamination of amino acids) at low concentrations is typically incorporated into glutamine (Madigan et al. 2003), the intracellular glutamine level may activate the urea synthesis as suggested for Pseudomonas aeruginosa (Jahns 1992). In contrast, the presence of extracellular urea has been found to induce urease synthesis in other bacteria (shown for Proteus mirabilis; Mobley et al. 1995). Uptake of extracellular urea may require an energy-dependent urea transport system as observed in Corynebacterium glutamicum when grown with urea as the only $\mathrm{N}$ source and at naturally low concentrations (Siewe et al. 1998). Thus, bacterial utilization of urea appears to necessitate energy for production of urease and possibly also for transport enzymes. This energy expenditure may restrict the utilization of urea-N by natural bacterioplankton.

In order to examine to which extent natural bacterial populations in diverse aquatic environments are capable of taking up urea and how this uptake may be influenced by utilization of other $\mathrm{N}$ compounds, assimilation of urea-N was studied in 3 estuaries in Denmark and 1 in Florida, USA. The uptake was related to the utilization of 'high quality' $\mathrm{N}$ sources such as DFAA and $\mathrm{NH}_{4}{ }^{+}$, and total $\mathrm{N}$ uptake by the bacteria. The various sites were chosen to characterize microbial urea dynamics in environments with a different biological activity but with a comparable trophic status. Various methodologies were applied in the different studies as the focus of the work has been to present general aspects of urea uptake and its control, rather than actual site-specific urea uptake rates at 4 locations. Briefly, the results indicate that urea may sustain a substantial portion of the bacterial $\mathrm{N}$ demand, although $\mathrm{NH}_{4}{ }^{+}$and DFAA generally appear to be more important $\mathrm{N}$ sources to estuarine bacteria.

\section{MATERIALS AND METHODS}

Sampling. Water was collected from the following locations: Roskilde Fjord, Knebel Vig and Limfjorden, Denmark, and Santa Rosa Sound, northwestern Florida, USA. All locations are estuarine sites influenced by anthropological activity to a varying degree. Short descriptions of the sampling sites and information on chemical and biological analyses are given in Table 1.

In order to reduce uptake or production of urea by organisms other than bacteria, the experimental setup typically consisted of batch cultures of natural water filtered through Whatman GF/F filters (nominal pore size of about $0.7 \mu \mathrm{m}$ ) or $0.8 \mu \mathrm{m}$ pore-size filtered water (cellulose nitrate filters, Millipore), which was inoculated into $0.2 \mu \mathrm{m}$ filtered water (Whatman Polycap filter capsules including a glass fibre prefilter) at a 1:9 ratio. Exceptions were the seasonal study in Roskilde Fjord in spring 1997 when bacterial production and uptake of urea and DFAA were measured in GF/C (exclusion size of about $1.4 \mu \mathrm{m}$ ) filtered water, and some of the studies in Knebel Vig in which urea uptake was studied in untreated water.

Analysis of dissolved nitrogen. Samples for chemical analyses were filtered through $0.2 \mu \mathrm{m}, 25 \mathrm{~mm}$ diameter cellulose acetate Millipore or Sartorius membrane syringe filters. The initial 1 to $2 \mathrm{ml}$ filtrate was discarded before the filtrates were stored frozen in $60 \mathrm{ml}$ acid-washed HDPE bottles (Nagle Nunc).

Dissolved $\mathrm{N}$ was determined as total dissolved $\mathrm{N}$ (TDN), including both dissolved inorganic and organic N (DIN and DON), using a Dohrman DN 1900 analyser (Teledyne Technologies). $\mathrm{NH}_{4}{ }^{+}, \mathrm{NO}_{3}{ }^{-}$and urea were measured on an AlpKem FlowSolution IV autoanalyzer (OI Analytical) using standard methods, except for urea, which was measured with the monoxime method according to Price \& Harrison (1987). Detection limits for $\mathrm{NO}_{3}{ }^{-}$and $\mathrm{NH}_{4}{ }^{+}$were 0.05 and $0.1 \mu \mathrm{mol}$ $\mathrm{l}^{-1}$, respectively.

Manual analysis of urea with the monoxime method is difficult to perform due to the high reaction temperature $\left(>85^{\circ} \mathrm{C}\right)$ to obtain a detectable color, the quickly fading color, and formation of precipitate during cooling (Mulvaney \& Bremer 1979, Price \& Harrison 1987). In this study, the fading color and precipitation prob- 


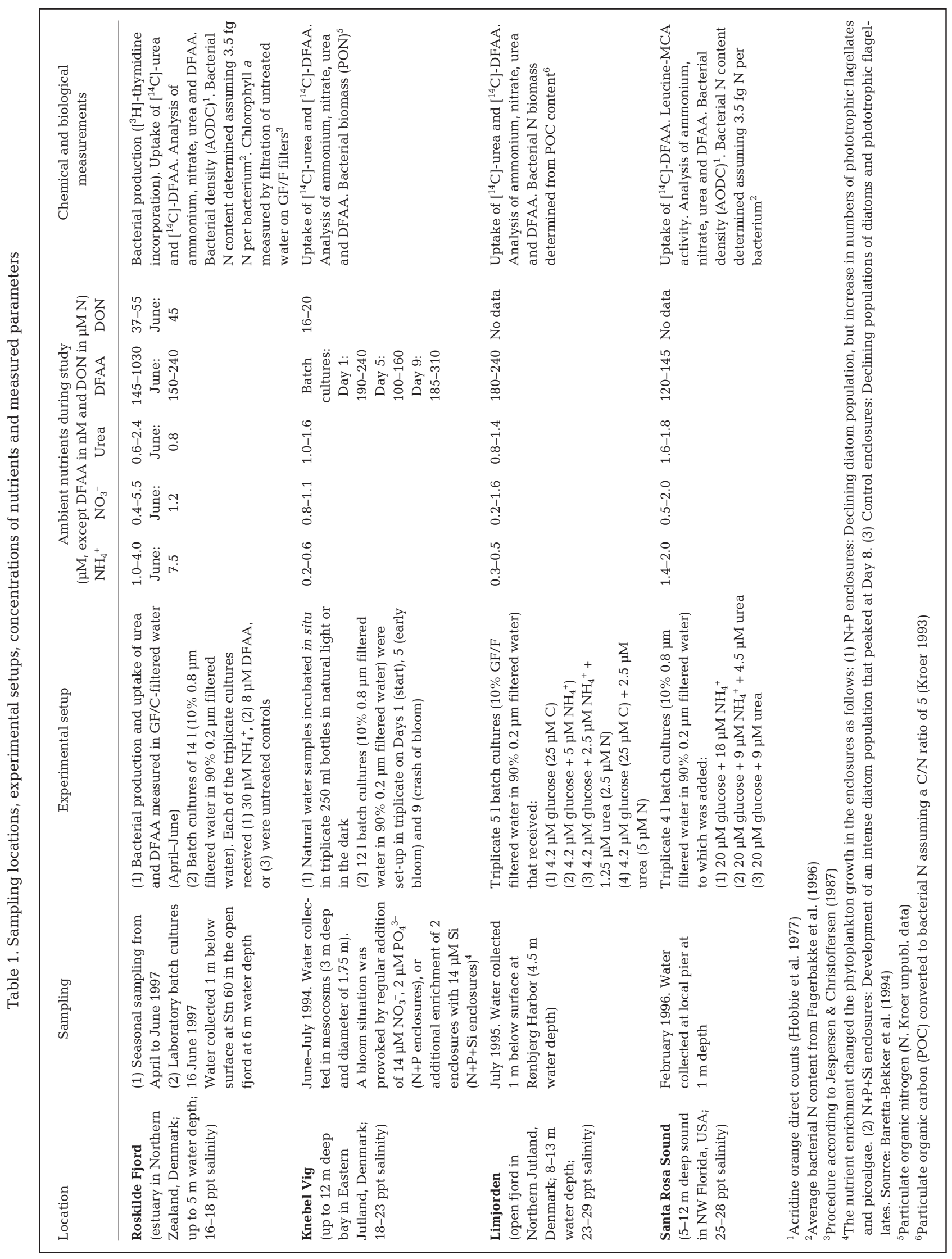


lems were eliminated by fast cooling with a high-precision cooling device. After mixing of reagents and sample at room temperature in the autoanalyzer, the sample tube was connected to a $1.2 \mathrm{~mm}$ diameter, coiled glass tube in a digitally temperature-controlled oil bath at $90.0^{\circ} \mathrm{C}\left(0.1^{\circ} \mathrm{C}\right)$. A higher temperature increased the color intensity, but increased the risk of bubble formation. The temperature of $90^{\circ} \mathrm{C}$ practically eliminated formation of bubbles. After heating for $9.5 \mathrm{~min}$ in the oil bath, the sample tube was cooled to $15^{\circ} \mathrm{C}$ in $2 \mathrm{~s}$ in a thermo-electric pieltier cooling element. The detection limit was about $0.1 \mu \mathrm{mol} \mathrm{l}^{-1}$ urea and a precision of $0.05 \mu \mathrm{mol} \mathrm{l^{-1 }}$.

Dissolved free amino acids (DFAA) were quantified as fluorescent $o$-phthaldialdehyde derivatives by HPLC according to Lindroth \& Mopper (1979) and Jørgensen et al. (1993).

Analysis of bacterial $\mathbf{N}$ biomass. Bacterial biomass in the Roskilde Fjord and Santa Rosa Sound samples was calculated assuming a bacterial $\mathrm{N}$ content of $3.5 \mathrm{fg}$ $\mathrm{N}$ (average value by Fagerbakke et al. 1996). In the Limfjorden batch cultures, the bacterial biomass was determined from carbon content of particles retained on a GF/F filter (analyzed by infrared gas analysis; M. Middelboe unpubl. data) and assuming a bacterial $\mathrm{C} / \mathrm{N}$ ratio of 5 (Kroer 1993). $\mathrm{N}$ content of bacteria in the Knebel Vig batch cultures was measured as particulate matter on GF/F filters which were assayed in a Carlo Erba NA 1500 CHN analyzer (Thermo Electron). Previous studies have shown that GF/F filters retain from 93 to $99 \%$ of marine bacteria in their late exponential phase when grown in batch cultures similar to the present cultures (Kroer 1994). Similar retention efficiency by filtration of bacteria onto GF/F filters was assumed in the present study as the bacterial biomass typically was harvested at maximum bacterial density.

Bacterial uptake of urea. Uptake (hydrolysis) of urea by bacteria was measured from production of ${ }^{14} \mathrm{CO}_{2}$ in triplicate $20 \mathrm{ml}$ water samples to which 60 to $75 \mathrm{nCi}$ (2.20 to $2.72 \mathrm{kBq}$ ) ${ }^{14} \mathrm{C}$-urea (Perkin Elmer) (= 54 to $68 \mathrm{nmol} \mathrm{l}^{-1}$, or a maximum of 5 to $10 \%$ of the natural concentrations) had been added. The samples were incubated in $100 \mathrm{ml}$ serum bottles with rubber membranes to which small plastic cups were fixed with accordion-folded paper wicks under the membrane. All incubations were done in the dark in the laboratory within $\pm 2^{\circ} \mathrm{C}$ of the in situ temperature. Incubation of field samples from Knebel Vig was initiated within $2 \mathrm{~h}$ of sample collection. The urea uptake was stopped after 75 to $210 \mathrm{~min}$ by injection of formaldehyde through the membranes. The samples were acidified with $10 \%$ phosphoric acid to drive off $\left[{ }^{14} \mathrm{C}\right]-\mathrm{CO}_{2}$, after which the wicks were soaked with $100 \mu \mathrm{l} \beta$-phenylethylamine to trap $\mathrm{CO}_{2}$. After $1 \mathrm{~h}$ on a shaking table, the $\mathrm{CO}_{2}$ traps were transferred to $20 \mathrm{ml}$ scintillation vials, which re- ceived $0.5 \mathrm{ml}$ Carbosorb $\mathrm{CO}_{2}$ absorber (Perkin Elmer) as an additional precaution to fix $\mathrm{CO}_{2}$ to the wicks, and $15 \mathrm{ml}$ of a commercial scintillation cocktail before counting. Turnover time of the urea isotope was assumed to be identical to the turnover time of ambient urea pool. It was further assumed that the $\mathrm{N}$ moiety of urea was incorporated into the bacterial biomass. In the bacterial cultures, the urea uptake was determined at regular intervals during the incubation periods.

Uptake of urea by production of $\left[{ }^{14} \mathrm{C}\right]-\mathrm{CO}_{2}$ from the added $\left[{ }^{14} \mathrm{C}\right]$ urea isotope was compared to uptake measured from changes in urea concentrations in the Limfjorden microcosms during $36 \mathrm{~h}$ (see 'Results' and Fig. 6B). A high agreement between the 2 approaches, except for the control series, indicates that both methods produce reliable measurements of urea uptake. The advantage of the isotope approach is that it allows detection of an uptake being too small to be registered from a difference in concentration. In most of the present experiments, the uptake of urea was too low to be detected by differences in concentration.

Bacterial DFAA uptake. Bacterial assimilation of DFAA was determined from net radiotracer incorporation and actual concentrations of the free amino acids. Triplicate $5 \mathrm{ml}$ water samples and a killed control (containing $2 \%$ formaldehyde) received $10 \mathrm{nCi}(367 \mathrm{~Bq}$ ) of the following $4\left[{ }^{14} \mathrm{C}\right]$-amino acids at equimolar concentrations: glutamic acid, serine, glycine and alanine (Perkin Elmer). These amino acids were chosen as the DFAA pool at the studied sites was dominated by acidic and neutral amino acids. Basic amino acids (asparagine, glutamine, lysine and ornithine) on the average made up a $7 \%$ (4 to $11 \%$ ) of all DFAA (data not shown). The added tracers did not exceed $1 \mathrm{nM}$ in concentration, corresponding to a maximum of 1 to $2 \%$ of their natural concentrations. The incubations were performed in the dark at a temperature within $\pm 2^{\circ} \mathrm{C}$ of the field temperature. The uptake was terminated after 30 to $40 \mathrm{~min}$ by addition of formaldehyde, followed by filtration through $0.2 \mu \mathrm{m}$ membrane filters at maximum $25 \mathrm{kPa}$ vacuum, rinsing with $0.2 \mu \mathrm{m}$ filtered water, and determination of radioactivity on the filters by liquid scintillation counting. Turnover rates of the 4 amino acids were assumed to represent uptake of all DFAA and were used to calculate the total DFAA turnover. Respiration of $\left[{ }^{14} \mathrm{C}\right]$-amino acids taken up by the bacteria was not measured. This means that the presented uptake rates, based on C-content of the DFAA, are net rates. For calculation of DFAA-N uptake, gross DFAA uptake rates were determined assuming a $50 \%$ respiration of the $\left[{ }^{14} \mathrm{C}\right]$-amino acids (Jørgensen 1987) and a C:N ratio of 3.2:1 of the amino acids. It was further assumed that all DFAA-N was incorporated into bacterial biomass. In the bacterial cultures, the uptake of $\left[{ }^{14} \mathrm{C}\right]$-DFAA was determined at regular intervals during the incubation periods. 
Bacterial production. The production of bacteria in the Roskilde Fjord samples was estimated from bacterial incorporation of $\left[{ }^{3} \mathrm{H}\right]$-thymidine (Fuhrman \& Azam 1980), using a conversion factor of $1.4 \times 10^{18}$ cells per mol thymidine incorporated (Riemann et al. 1990).

Amino peptidase assay. Amino peptidase activity was measured in the Santa Rosa Sound samples by addition of the substrate analogue leucine-MCA (SigmaAldrich) to subsamples from the bacterial cultures. Enzymatic cleavage of leucine from the leucine-MCA compound is assumed to represent the bacterial amino peptidase activity. The enzyme activity was measured in quadruple $2 \mathrm{ml}$ samples in clear $4 \mathrm{ml} 4$-way plastic cuvettes with a final leucine-MCA concentration of $2 \mu \mathrm{M}$. The samples were incubated for $5 \mathrm{~h}$ within $\pm 2^{\circ} \mathrm{C}$ of the field temperature. Fluorescence of the produced
AMC (the compound formed after cleavage of the leucine-MCA bond) was measured on a LS50 PerkinElmer spectrofluorometer at $380 \mathrm{~nm}$ excitation and $440 \mathrm{~nm}$ emission wavelengths with a $3 \mathrm{~s}$ integration time. AMC standards of 0 to $5 \mu \mathrm{M}$ were used to convert fluorescence intensity to amino peptidase activity.

\section{RESULTS}

\section{Urea uptake in Roskilde Fjord}

From 17 April to 24 June, the urea concentration in the fjord was $<1 \mu \mathrm{M}$, except for $1.35 \mu \mathrm{M}$ on 13 May, and was typically lower than the concentration of ammonium and nitrate (Fig. 1A). Concentrations of
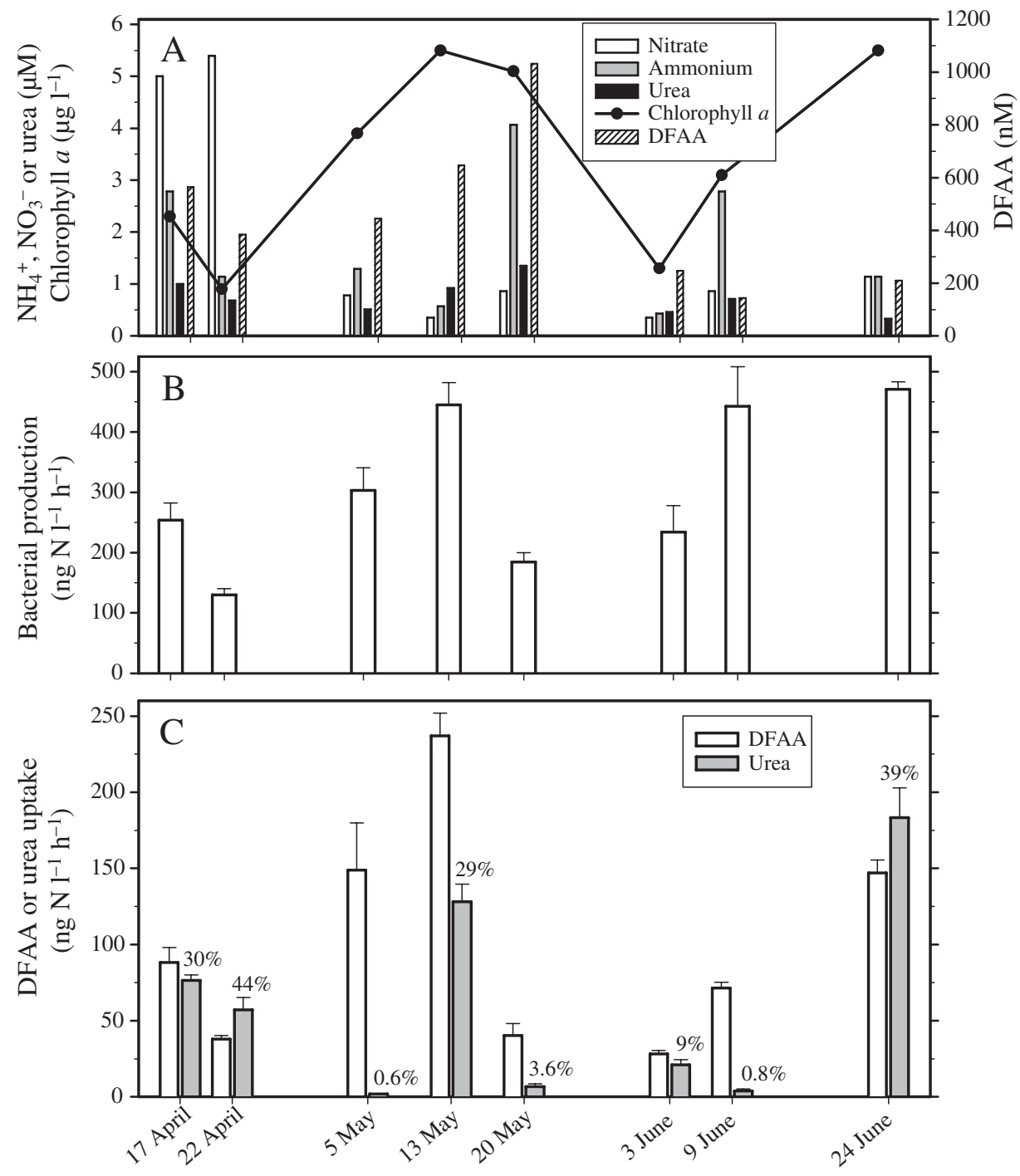

Fig. 1. Seasonal study in Roskilde Fjord. (A) Concentrations of nitrate, ammonium, urea, DFAA and chlorophyll $a$, (B) bacterial production (incorporation of ${ }^{3} \mathrm{H}$-thymidine), and (C) uptake of DFAA and urea. Means \pm 1 SD shown. $\mathrm{n}=3$, except in (A) where no replicates were analyzed (typical analytical variation was 4 to $7 \% \mathrm{~N}$ compounds and 8 to $10 \%$ chlorophyll a) 
DFAA ranged from 140 to $650 \mathrm{nM}$, except for $1030 \mathrm{nM}$ on 20 May, and covaried with concentrations of urea (Spearman rank correlation $\mathrm{p}<0.05$ ). Chlorophyll $a$ in the fjord water varied from 0.9 to $5.5 \mu \mathrm{g} \mathrm{l^{-1 }}$ and had highest concentrations in mid May and late June.

In GF/C-filtered fjord water, the bacterial production

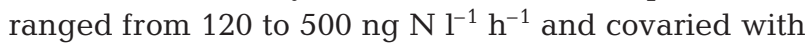
the amount of chlorophyll in the untreated water (Spearman rank correlation $\mathrm{p}<0.02$ ) (Fig. 1B). The uptake of urea varied significantly, ranging from 1.8 (5 May) to $183 \mathrm{ng} \mathrm{N}^{-1} \mathrm{~h}^{-1}$ (24 June) (Fig. 1C). In contrast, assimilation of DFAA was less variable during the period (28 to $237 \mathrm{ng} \mathrm{N}^{-1} \mathrm{~h}^{-1}$ ). Assimilation of DFAA correlated with the bacterial production (Spearman rank correlation $\mathrm{p}<0.02$ ), but changes of the urea uptake rates did not correlate with any of the measured parameters (concentration of urea, $\mathrm{NH}_{4}{ }^{+}, \mathrm{NO}_{3}{ }^{-}$, bacterial production or DFAA assimilation; $\mathrm{p}>0.05$ ).

Uptake of urea was estimated to sustain from 0.6 to $44 \%$ (mean of $19.5 \%$ ) of the bacterial $\mathrm{N}$ demand (indicated above the urea columns in Fig. 1C). This was about 1.5-fold lower than the $\mathrm{N}$ contribution by DFAA, which was determined to 12 to $53 \%$ with a mean of $31 \%$.

\section{Effect of $\mathbf{N}$ enrichment on urea uptake by Roskilde Fjord bacteria}

Addition of $\mathrm{NH}_{4}{ }^{+}$or DFAA to batch cultures of bacteria from Roskilde Fjord in June 1997 caused a 2-fold higher cell production in the DFAA-enriched cultures than in the $\mathrm{NH}_{4}{ }^{+}$-enriched and the unenriched control cultures (Fig. 2A). Urea uptake in the controls was on average 2-fold higher than in the $\mathrm{NH}_{4}{ }^{+}$- and DFAAenriched cultures, except after $42 \mathrm{~h}$ when uptake of urea in the controls was up to 10-fold higher (Fig. 2B). In the DFAA-enriched cultures, up to 5-fold higher DFAA assimilation rates occurred, relative to the control and $\mathrm{NH}_{4}{ }^{+}$cultures (data not shown).

Integration of $\mathrm{N}$ uptake by urea and DFAA during the $150 \mathrm{~h}$ incubation period showed that urea was a minor N source to the bacteria, making up from $0.32 \%$ (+DFAA cultures) to $3.3 \%$ (controls) of the DFAA assimilation (Fig. 2C). DFAA-N sustained 129\% (control), $116 \%\left(+\mathrm{NH}_{4}{ }^{+}\right.$cultures) and $220 \%$ (+DFAA cultures) of the bacterial $\mathrm{N}$ demand, assuming a $\mathrm{N}$ content of $3.5 \mathrm{fg}$ N per cell. The apparent $>100 \% \mathrm{~N}$ contribution by DFAA to the bacterial $\mathrm{N}$ biomass probably
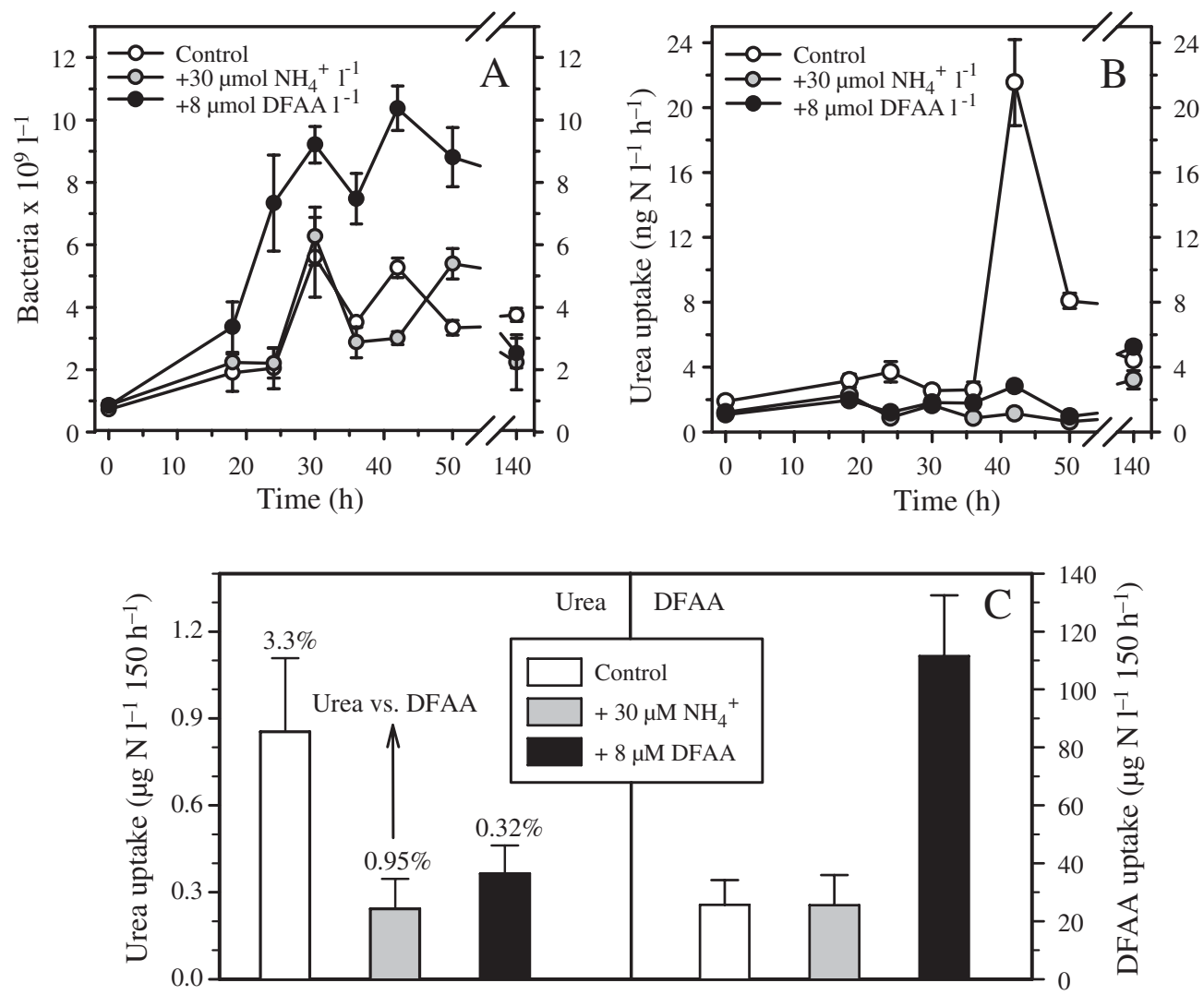

Fig. 2. Effect of enrichment with ammonium and DFAA on growth and urea uptake by Roskilde Fjord bacteria. (A) Bacterial density, (B) uptake of urea, and (C) $150 \mathrm{~h}$ integrated urea and DFAA uptake, including indication of urea-N vs. DFAA-N uptake. At start of the incubation, the ambient DFAA, urea and ammonium concentrations were $280 \mathrm{nM}, 400 \mathrm{nM}$ and $7.5 \mu \mathrm{M}$, respectively. Means $\pm 1 \mathrm{SD}, \mathrm{n}=3$. Error bars of the integrated rates in $(\mathrm{C})$ were determined by least squares method 
reflects that the bacterial $\mathrm{N}$ content exceeded the applied literature value of $3.5 \mathrm{fg} \mathrm{N}$ per cell.

\section{Bacterial N sources during a provoked algal bloom in Knebel Vig}

During a stimulated summer algal bloom in mesocosms (enclosures) in Knebel Vig, $0.8 \mu \mathrm{m}$-filtered water was collected Day 1 (12 h after addition of $\mathrm{N}+\mathrm{P}$ or $\mathrm{N}+\mathrm{P}+\mathrm{Si}$ ) and Days 5 and 9 . Bacterial uptake of urea, DFAA, $\mathrm{NH}_{4}{ }^{+}$and $\mathrm{NO}_{3}{ }^{-}$in the filtered water was subse- quently examined in batch cultures during $42 \mathrm{~h}$. Uptake rates of urea and DFAA were rather similar in the 3 sets of cultures at Day 1, but at Days 5 and 9 the rates varied between the cultures (Fig. 3). At Day 5, the DFAA assimilation was similar in water from the $\mathrm{N}+\mathrm{P}$ and $\mathrm{N}+\mathrm{P}+\mathrm{Si}$ enclosures and was 2 -fold higher than in the controls. The urea uptake was slightly higher in the controls than in the $\mathrm{N}+\mathrm{P}+\mathrm{Si}$ cultures, while it was insignificant in the $\mathrm{N}+\mathrm{P}$ cultures. At Day 9, the lowest DFAA assimilation and highest urea uptake occurred in the controls. In the $\mathrm{N}+\mathrm{P}$ and $\mathrm{N}+\mathrm{P}+\mathrm{Si}$ cultures, a higher DFAA uptake was measured concurrent with

Day 1
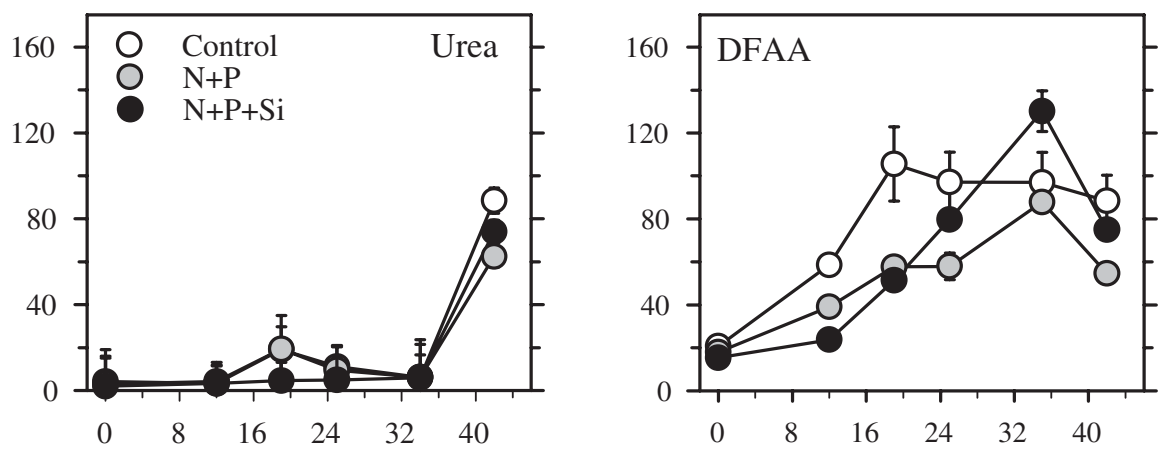

Day 5
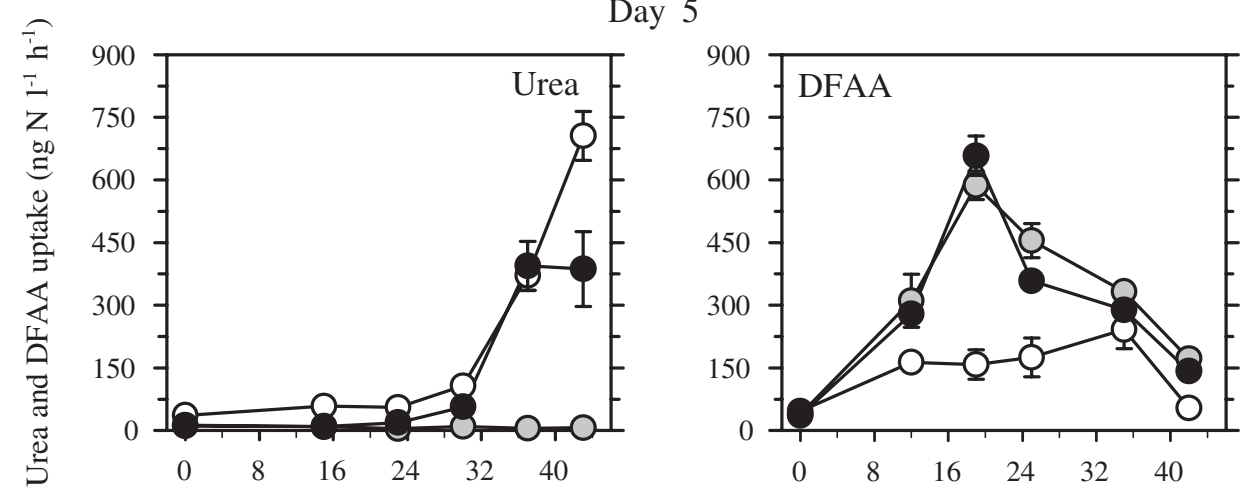

Day 9
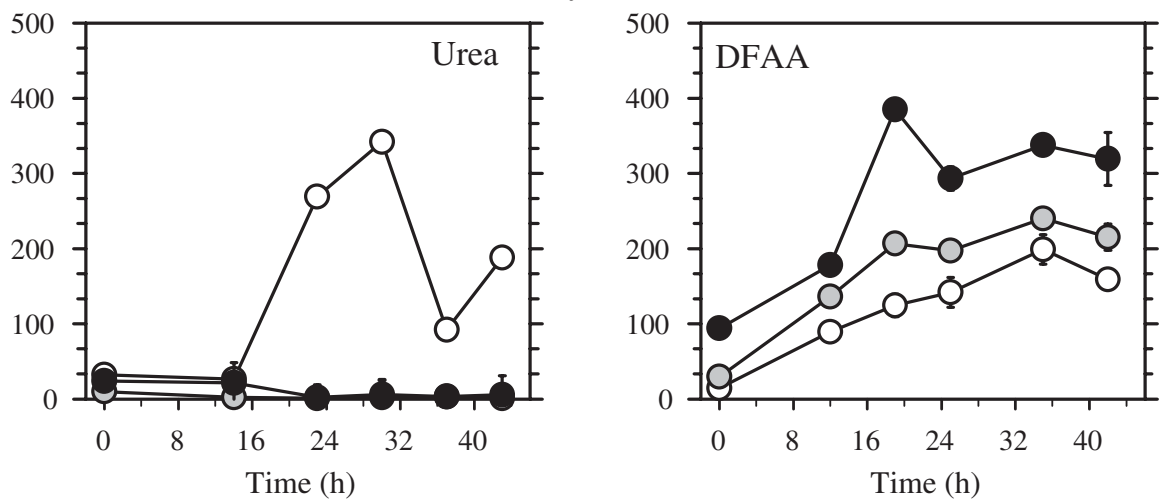

Fig. 3. Bacterial N dynamics in $0.8 \mu \mathrm{m}$-filtered water from Knebel Vig mesocosms enriched with $\mathrm{N}+\mathrm{P}$ or N+P+Si. Water from the mesocosms was collected on Days 1, 5 and 9 and used for bacterial batch cultures. Uptake rates of urea and DFAA in the 3 types of batch cultures are shown. Means $\pm 1 \mathrm{SD}, \mathrm{n}=3$ 
an insignificant urea uptake. The bacterial density in the cultures at Day 1 covaried with the uptake of urea but not of DFAA (Spearman rank correlation $\mathrm{p}<0.05$ and $\mathrm{p}>0.05$, respectively) (data not shown). Unfortunately, no bacterial counts were done in the Day 5 and 9 cultures.

Uptake rates of urea and DFAA did not correlate with concentration changes of either urea or DFAA in the water (Spearman rank correlations $\mathrm{p}>0.05$ ). Urea varied between 0.5 and $0.8 \mu \mathrm{M}$ in the cultures (no trends were found), while the lowest and highest concentrations of DFAA were measured in the Days 5 and 9 cultures (100 to $160 \mathrm{nM}$ and 185 to $310 \mathrm{nM}$, respectively). Intermediary DFAA concentrations of 190 to 240 nM occurred at Day 1.
The bacterial $\mathrm{N}$ biomass in the cultures increased from Day 1 to Day 9, except for a minor decline from Days 5 to 9 in the N+P cultures (Fig. 4A). The highest bacterial cell production was found in the N+P+Si cultures at Day 9 (6.5-fold increase relative to Day 1).

Integrated uptake rates of DFAA and urea (from the ${ }^{14} \mathrm{C}$ tracer studies), and concentration changes of $\mathrm{NH}_{4}{ }^{+}$ and $\mathrm{NO}_{3}{ }^{-}$during the incubations, demonstrated that DFAA and $\mathrm{NH}_{4}{ }^{+}$were more important $\mathrm{N}$ sources than urea to the bacteria, but the results also showed an uptake of $\mathrm{NO}_{3}{ }^{-}$in most cultures (Fig. 4B). Urea sustained 0.2 to $8 \%(\mathrm{~N}+\mathrm{P}$ cultures), 0.1 to $30 \%(\mathrm{~N}+\mathrm{P}+\mathrm{Si}$ cultures) and 9 to $41 \%$ (control) of the bacterial $\mathrm{N}$ demand. Like DFAA and urea, the variable uptake of $\mathrm{NH}_{4}{ }^{+}$appeared not to depend on the actual pools in the water, as rather similar concentrations of $\mathrm{NH}_{4}{ }^{+}$occurred in the enclosures (0.2 to $0.6 \mu \mathrm{M})$. Similarly, change to $\mathrm{NO}_{3}{ }^{-}$appeared not to be controlled by the concentration, as a higher uptake occurred in the controls (about ca. $1 \mu \mathrm{M} \mathrm{NO}{ }_{3}^{-}$) than in the $\mathrm{N}+\mathrm{P}+\mathrm{Si}$ cultures (about $18 \mu \mathrm{M} \mathrm{NO}_{3}{ }^{-}$). Uptake of the studied $\mathrm{N}$ sources on the average sustained $107 \%$ of the bacterial $\mathrm{N}$ demand, ranging from $67 \% \quad(\mathrm{~N}+\mathrm{P}$ cultures, Day 9) to $147 \%$ (control cultures, Day 9; Fig. 4B).

Uptake of urea in the cultures was related to the in situ urea uptake in the enclosures (by alga and bacteria), at either ambient light or in the dark (3 h dark pre-incubated samples). Urea uptake in the dark might be expected to reflect the bacterial uptake, assuming that algal uptake of urea only occurred in the light (see 'Discussion'). A summary of results from Days 1, 5 and 9 shows that urea uptake during $42 \mathrm{~h}$ in the cultures made up from 8 to $450 \%$ (mean of $158 \%$ ) of the dark community uptake, and that the community uptake at in situ light was 3.4 to 282-fold (mean of 15.8-fold if excluding the extreme high value of 282) above the dark community urea uptake. Details were as follows: On Day 1, urea uptake in the bacterial cultures made up 30 to $60 \%$ of the in situ dark uptake, but the dark uptake was 10 to 19 -fold below that at in situ light (Fig. 5). On Day 5, urea uptake in the bacterial cultures was from 0.08 -fold $(\mathrm{N}+\mathrm{P})$ to 1.7 -fold (control) and 4.5-fold $(\mathrm{N}+\mathrm{P}+\mathrm{Si})$ higher
Fig. 4. Bacterial N dynamics in Knebel Vig mesocosms. (A) Bacterial N biomass after $42 \mathrm{~h}$ growth in batch cultures from Days 1,5 and 9, and (B) $42 \mathrm{~h}$ integrated uptake of urea, DFAA, ammonium and nitrate. In (B), * indicates that the contribution of $\mathrm{N}$ from urea, DFAA, ammonium and nitrate exceeded the measured $\mathrm{N}$ biomass ( $t$-test, $\mathrm{p}<0.05$ ). Means $\pm 1 \mathrm{SD}, \mathrm{n}=3$ in (A) only 


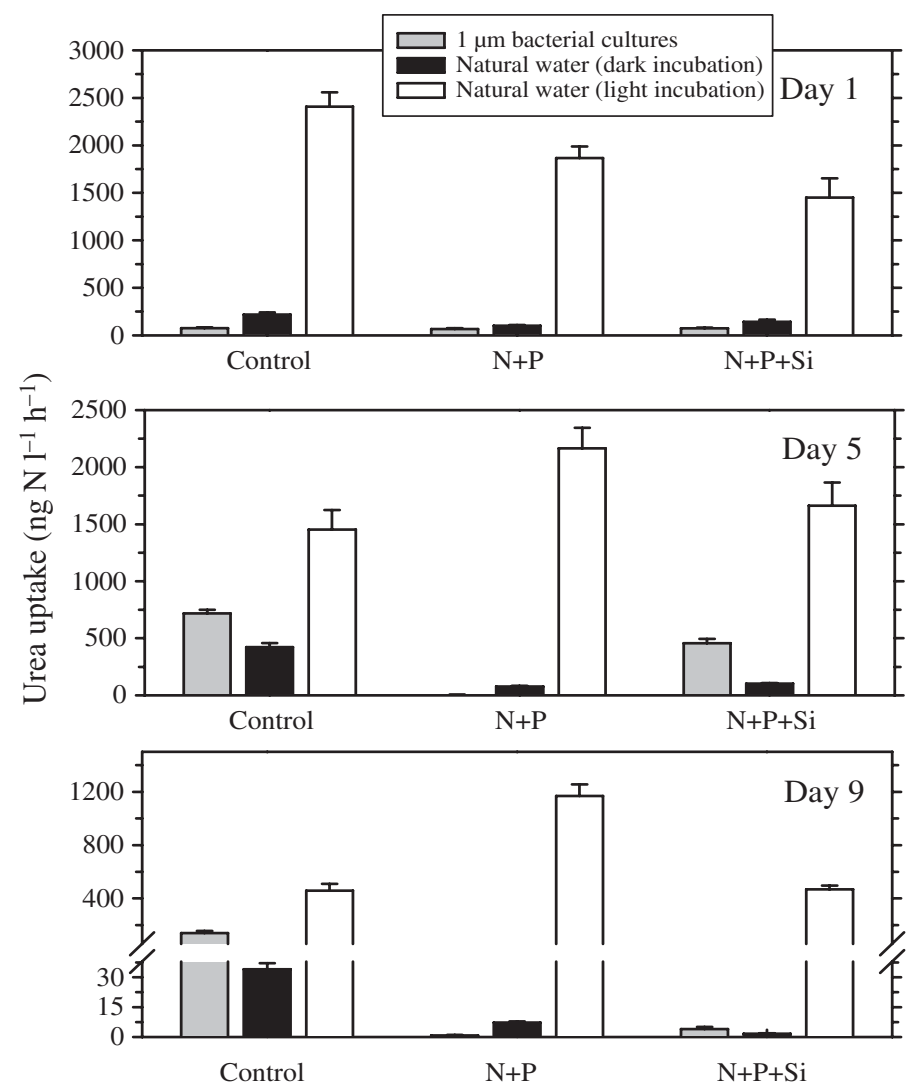

Fig. 5. Bacterial $\mathrm{N}$ dynamics in Knebel Vig mesocosms. Uptake of urea in the bacterial batch cultures $(10 \% 0.8 \mu \mathrm{m}$ filtered and $90 \% 0.2 \mu \mathrm{m}$ filtered water), and in untreated mesocosm water in the dark or in natural mid-day daylight on Days 1, 5 and 9. For the bacterial batch cultures the highest measured rate during the $42 \mathrm{~h}$ incubation periods is shown. Means $\pm 1 \mathrm{SD}, \mathrm{n}=3$

than in the in situ dark samples. Urea uptake at in situ light was from 3.4-fold (control) to 16 -fold $(\mathrm{N}+\mathrm{P}+\mathrm{Si}$ ) and 28-fold $(\mathrm{N}+\mathrm{P})$ higher than in the in situ dark incubations. Finally at Day 9, urea uptake in the bacterial cultures was from 0.11 -fold $(\mathrm{N}+\mathrm{P})$ to 2.3 -fold $(\mathrm{N}+\mathrm{P}+\mathrm{Si})$ and 4.1-fold (control) higher than in the in situ dark samples. At in situ light, urea uptake was from 13-fold (control) to 16-fold (N+P) and 282-fold (N+P+Si) higher than in the corresponding dark incubations.

\section{Effect of enrichment with glucose, $\mathrm{NH}_{4}{ }^{+}$and urea on urea uptake by Limfjorden bacteria}

The amount of available carbon (glucose) and $\mathrm{N}$ $\left(\mathrm{NH}_{4}{ }^{+}\right.$and/or urea at a $\mathrm{C} / \mathrm{N}$ ratio of 5) was manipulated in batch cultures of bacteria from the Limfjorden to study the effect on uptake of urea. Relative to the unamended controls, glucose alone did not stimulate the cell production, but addition of glucose together with $\mathrm{NH}_{4}{ }^{+}$and/or urea increased the bacterial production by a factor of 2 (Fig. 6A). Enrichment with glucose and
$\mathrm{NH}_{4}{ }^{+}$led to an 8 to 10 -fold higher uptake of $\mathrm{NH}_{4}{ }^{+}$but also a 2-fold higher assimilation of DFAA, while urea uptake remained unchanged. In the cultures enriched with glucose, $\mathrm{NH}_{4}{ }^{+}$and urea, urea and DFAA uptake was similar to that in the glucose $+\mathrm{NH}_{4}{ }^{+}$cultures, but $\mathrm{NH}_{4}{ }^{+}$uptake was reduced by $26 \%$. The effect of addition of only glucose and urea was a $60 \%$ higher uptake of urea, a small release of $\mathrm{NH}_{4}{ }^{+}$(no uptake) and a reduced DFAA assimilation. A small uptake of $\mathrm{NO}_{3}{ }^{-}$of about $1 \mu \mathrm{g} \mathrm{N}{ }^{-1}$ was measured in all cultures

Urea sustained 32 to $35 \%$ of the $\mathrm{N}$ demand in the control and glucose-enriched cultures. In the cultures enriched with both glucose, $\mathrm{NH}_{4}{ }^{+}$and/or urea, the $\mathrm{N}$ sustenance by urea increased with a declining $\mathrm{NH}_{4}{ }^{+}$ addition, and urea met from $17 \%\left(+\mathrm{NH}_{4}{ }^{+}\right.$and glucose $)$ to $41 \%$ (+ urea and glucose) of the bacterial $\mathrm{N}$ demand.

The bacterial uptake of urea was determined by both reduction in concentration during the incubation and by production of ${ }^{14} \mathrm{CO}_{2}$ from the added ${ }^{14} \mathrm{C}$ urea isotope (Fig. 6B). Except for the controls, no difference between the 2 approaches was found (analysis of normalized data by Mann-Whitney Rank sum test, $\mathrm{p}<0.05)$.
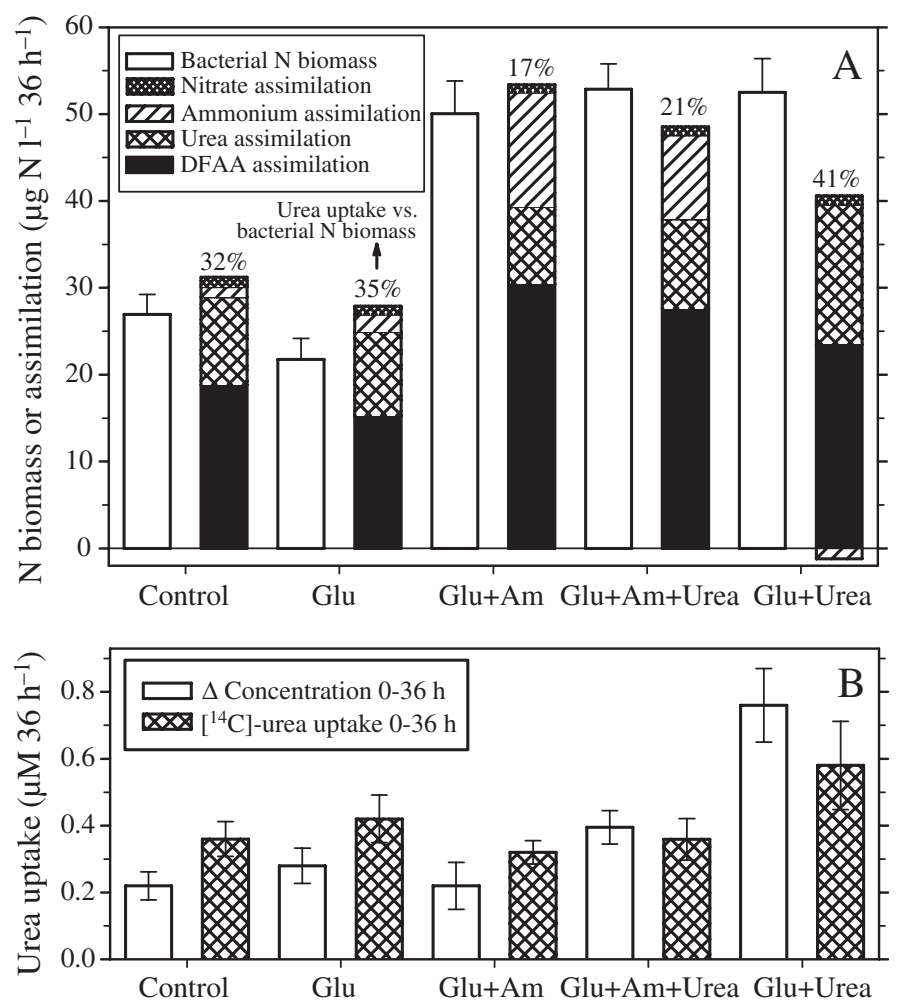

Fig. 6. Bacterial $\mathrm{N}$ uptake and $\mathrm{N}$ budgets in Limfjorden batch cultures. (A) Bacterial $\mathrm{N}$ biomass and integrated uptake of DFAA, urea, ammonium and nitrate after $36 \mathrm{~h}$ in the cultures. The contribution of urea $\mathrm{N}$ to the total bacterial $\mathrm{N}$ is indicated. (B) Comparison of urea uptake rates measured from changes in concentration and from production of ${ }^{14} \mathrm{CO}_{2}$ in ${ }^{14} \mathrm{C}$ urea. Means $\pm 1 \mathrm{SD}, \mathrm{n}=3$ (except for the integrated rates in $\mathrm{A}$ ) 

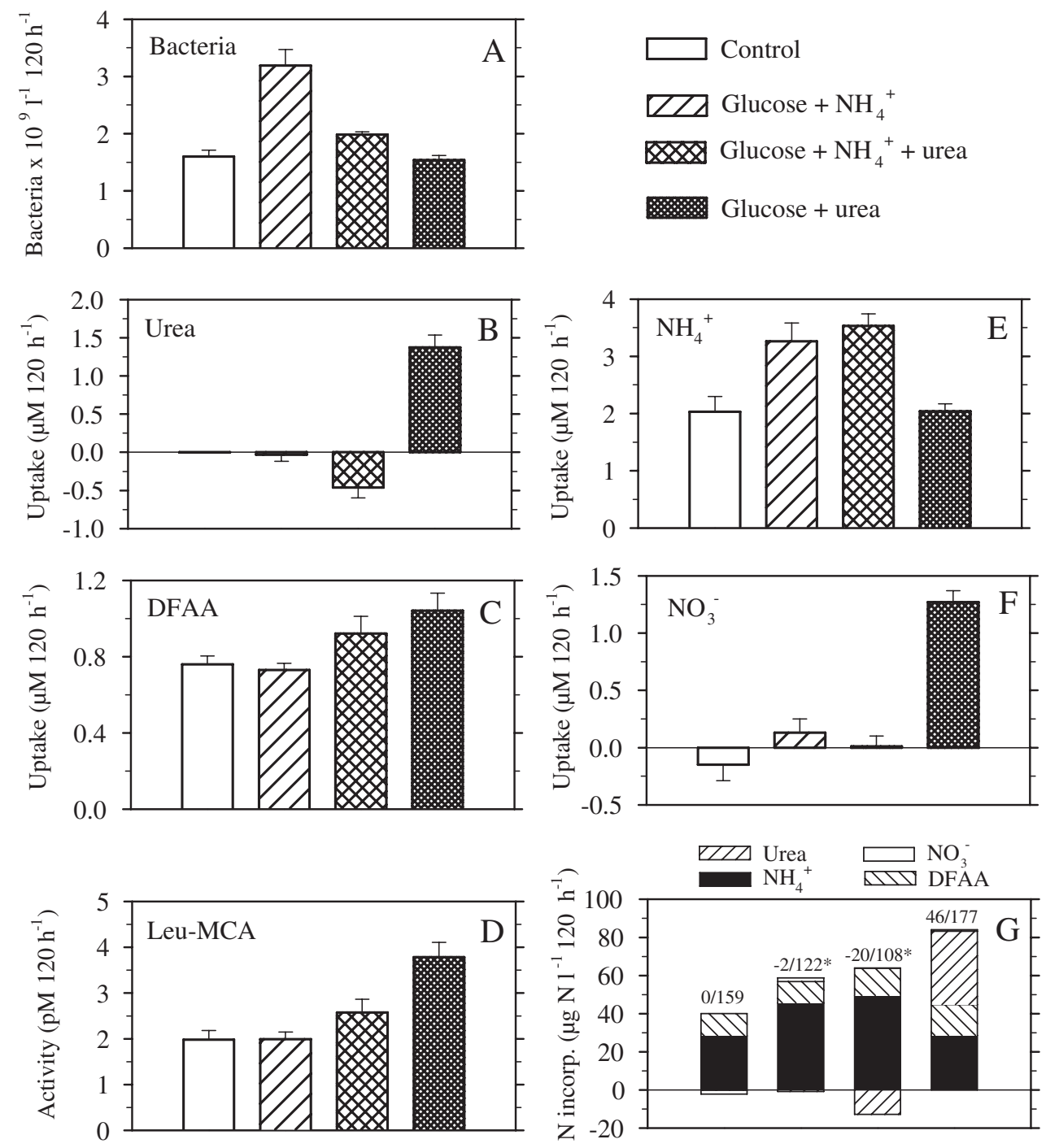

Fig. 7. Bacterial N uptake in Santa Rosa Sound batch cultures after $120 \mathrm{~h}$ incubation. (A) Bacterial densities, (B) uptake or release of urea (from difference in concentration at $120 \mathrm{~h}$ ), (C) integrated uptake of DFAA (from uptake of ${ }^{14} \mathrm{C}$ amino acids), (D) integrated peptidase activity (leucine-MCA), (E,F) uptake or release of ammonium and nitrate (from differences in concentration at $120 \mathrm{~h}$ ), and (G) $120 \mathrm{~h}$ integrated uptake (or release) of urea, ammonium, nitrate and DFAA. In (G), numbers above the columns are identical to those shown in Fig. $4 \mathrm{~B}_{i}{ }^{*}$ indicates that contribution of $\mathrm{N}$ from urea, DFAA, ammonium and nitrate was not different from the measured $\mathrm{N}$ biomass $(t$-test, $\mathrm{p}<0.05)$. In $(\mathrm{A})$, error bars indicate SE of 10 microscope fields counted. In (B), (E) and

$(F)$, error bars $=S D, n=3$. In $(C),(D)$ and $(G)$ error bars of the integrated rates were determined by least squares method

\section{Effect of enrichment with glucose, $\mathrm{NH}_{4}{ }^{+}$and urea on urea uptake by Santa Rosa Sound bacteria}

Bacterial utilization of urea and other $\mathrm{N}$ compounds after addition of $\mathrm{C}$ (glucose) and $\mathrm{N}\left(\mathrm{NH}_{4}{ }^{+}\right.$and/or urea) was examined over $120 \mathrm{~h}$ in batch cultures with subtropical, estuarine bacteria. The addition of $\mathrm{N}$ was

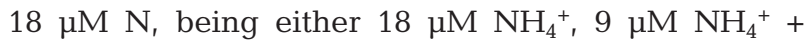
$4.5 \mu \mathrm{M}$ urea, or $9 \mu \mathrm{M}$ urea. Relative to unamended control cultures, effects of the increasing urea concentration were: (1) a declining bacterial production, (2) uptake of urea (only in the cultures enriched with glucose + urea), (3) an increased DFAA assimilation and leu-MCA activity, and (4) uptake of $\mathrm{NH}_{4}{ }^{+}$which declined in the $9 \mu \mathrm{M}$ urea-enriched cultures, simultaneous with an uptake of $\mathrm{NO}_{3}^{-}$(Fig. 7A-F).

The stimulated uptake of DFAA and $\mathrm{NO}_{3}{ }^{-}$and the higher leu-MCA activity, when urea was the major $\mathrm{N}$ source, suggest that urea was a less efficient or attractive $\mathrm{N}$ source than $\mathrm{NH}_{4}{ }^{+}$and DFAA. Despite the declining bacterial production with the higher urea concentrations, the amount of $\mathrm{N}$ utilized by the bacteria increased. Thus, the total $\mathrm{N}$ incorporation (as $\mu \mathrm{g} \mathrm{N}$ $\mathrm{l}^{-1} 120 \mathrm{~h}^{-1}$ ) was determined to 40 (control), 58 (glucose 
$+\mathrm{NH}_{4}^{+}$), 64 (glucose $+\mathrm{NH}_{4}{ }^{+}+$urea), and 83 (glucose + urea). Relative to the bacterial biomass production, the utilized $\mathrm{N}$ compounds made up from 108 to $177 \%$ of the estimated bacterial $\mathrm{N}$ production (Fig. $7 \mathrm{G}$ ). Only in the glucose + urea cultures was an incorporation of urea found (met $46 \%$ of the biomass production), and no release of $\mathrm{NH}_{4}{ }^{+}$(expected $\mathrm{N}$ degradation product of urea) was observed in these cultures.

\section{DISCUSSION}

Ammonium and amino acids have typically been considered dominant $\mathrm{N}$ sources to pelagic, heterotrophic bacteria (Kirchman 2000), but the present scenarios demonstrate that urea may also sustain a sizable portion of the $\mathrm{N}$ demand by aquatic bacteria. When the highest urea uptake rates were measured in the spring in Roskilde Fjord and in batch cultures with Knebel Vig and Limfjorden bacteria, urea met $>30 \%$ of the bacterial $\mathrm{N}$ demand and exceeded the DFAA-N assimilation. However, at other sampling times in Roskilde Fjord and in some of the batch cultures, urea uptake made up $<1 \%$ of the bacterial $\mathrm{N}$ demand. The mechanisms causing these variations are not obvious, but availability and composition of organic and inorganic nutrients, specific bacterial $\mathrm{N}$ preferences, as well as varying uptake capacities for different $\mathrm{N}$ compounds may be among the factors controlling the urea uptake.

\section{Uptake capacity for urea by bacterial populations}

Among identified Gram-positive and Gram-negative bacteria, only a fraction possess urease activity (search performed on the 'Prokaryotes' website, http://link. springer-ny.com/link/service/books/10125/) and therefore, presence of urease has been used as a taxonomic character. As mentioned previously, synthesis of urease in bacteria may be controlled by the general N status, including intracellular levels of glutamine and ammonium, as well as the extracellular urea concentration (Jahns 1992, Mobley et al. 1995). In some urease-positive bacteria, uptake of urea depends on a specific transport protein complex, such as an ATP-binding cassette (ABC) transporter as recently identified in Corynebacterium glutamicum (Beckers et al. 2005). In this bacterium, genes encoding the urea transporter and urease synthesis are controlled by the same global $\mathrm{N}$ regulator protein (Beckers et al. 2005), but it is unknown if this control system is commonly occurring in urease-positive bacteria.

An additional controlling factor in utilization of urea may be a slow uptake capacity. In Corynebacterium glutamicum maximum uptake rates for urea have been determined to 2.0 to $3.5 \mathrm{nmol} \mathrm{mg} \mathrm{dw}{ }^{-1} \mathrm{~min}^{-1}$ (Siewe et al. 1998). Applying these rates to the present estuarine bacteria, cell-specific uptake rates of 8 to $13 \mathrm{amol} \mathrm{h}^{-1}$ cell $^{-1}\left(\mathrm{a}=10^{-18}\right)$ were found (assuming a cell volume of $0.2 \mu^{-3}$ and an average cell weight of $64 \mathrm{fg}$ (Simon \& Azam 1989). This is a slow uptake, e.g. when related to the maximum uptake potential for amino acids of 150 amol cell ${ }^{-1} \mathrm{~h}^{-1}$ as measured by attached bacteria in the Mediterranean (Ayo et al. 2001). Although uptake rates of a $C$. glutamicum laboratory culture and natural, aquatic bacterial populations may not be directly comparable, the large difference in rates suggests that bacteria have a slower uptake of urea than of free amino acids. If applying the C. glutamicum uptake rates to the entire bacterial community in, e.g. the Knebel Vig batch cultures (assuming $5 \times 10^{9}$ bacteria $\mathrm{l}^{-1}$, each with a cell weight of $64 \mathrm{fg}$ ), the community uptake rate is estimated to 45 to $80 \mathrm{nmol}$ urea $\mathrm{l}^{-1} \mathrm{~h}^{-1}$. This agrees with the maximum rate of about $50 \mathrm{nmol}$ $\mathrm{l}^{-1} \mathrm{~h}^{-1}$ measured in the Knebel Vig control cultures Day 5, but in most experiments the bacterial uptake was $<2 \mathrm{nmol} \mathrm{l}^{-1} \mathrm{~h}^{-1}$. Since urease-positive bacteria most likely only made up a fraction of the bacterial populations in the estuarine water, the estimate suggests that bacteria in the Knebel Vig cultures occasionally had an uptake capacity at least corresponding to the maximum rate of $C$. glutamicum.

Based on the considerations above, factors that may have influenced uptake of urea by the estuarine bacteria include: (1) limited number of bacterial species being capable of taking up urea, (2) a relatively slow uptake system, (3) lack of energy required for synthesis of urease and transport enzymes, and (4) a general $\mathrm{N}$ control that favors free $\mathrm{NH}_{4}{ }^{+}$and amino acid-derived $\mathrm{NH}_{4}^{+}$to urea.

\section{Relations between uptake of urea and DFAA and $\mathrm{NH}_{4}^{+}$}

If availability of 'high quality' $\mathrm{N}$ such as amino acid $\mathrm{N}$ or $\mathrm{NH}_{4}{ }^{+}$is a major controlling factor to the uptake of urea, a high uptake of urea by the estuarine bacteria might be expected to coincide with low uptake rates and/or low concentrations of $\mathrm{NH}_{4}{ }^{+}$and DFAA. A plot of in situ uptake rates of DFAA vs. uptake rates of urea in Roskilde Fjord from April to June did not confirm such a correlation, although a declining uptake of DFAA coincided with an increased urea uptake at half of the sampling days (Fig. 8A). Further, no trends between concentrations of DFAA, urea, $\mathrm{NH}_{4}{ }^{+}$and $\mathrm{NO}_{3}{ }^{-}$and uptake of DFAA or urea were obvious as indicated by correlation analyses (see 'Results') and as exemplified in text fields in Fig. 8A. Only a correlation between DFAA uptake and bacterial production was found in the seasonal study. 

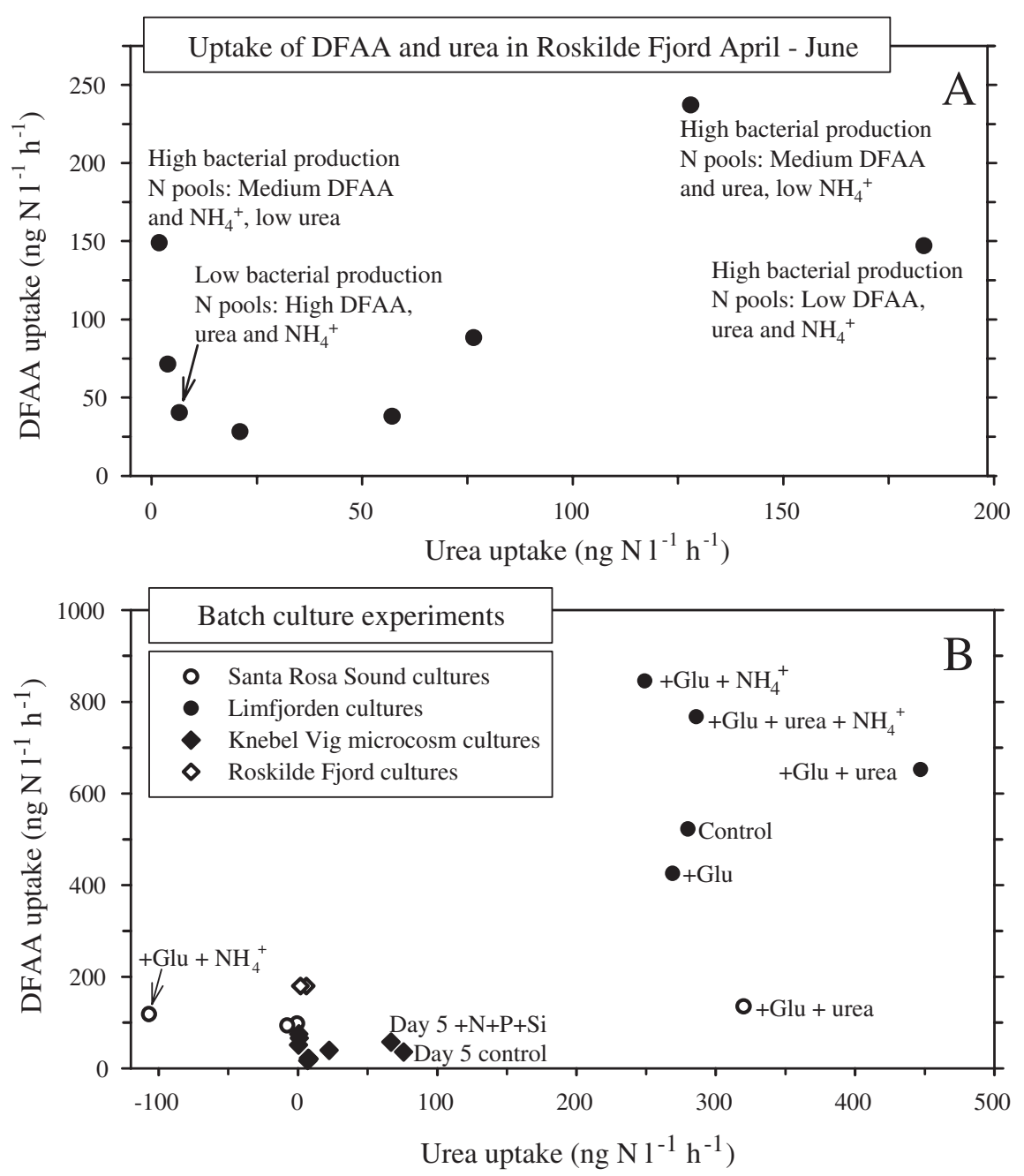

Fig. 8. (A) Uptake rates of DFAA vs. urea in the Roskilde Fjord seasonal study and (B) in the 4 series of batch cultures. Rates in (B) are average rates during the incubation periods to allow a comparison with rates in (A)

In contrast to the seasonal study of in situ uptake of urea and DFAA in Roskilde Fjord, there were indications of a 'high quality' control of urea uptake in the batch culture experiments. In the Roskilde Fjord cultures, the urea uptake was reduced to one-third when enriched with $30 \mu \mathrm{M} \mathrm{NH}{ }_{4}^{+}-\mathrm{N}$ or DFAA-N, respectively. The reduction in urea uptake, whether DFAA or $\mathrm{NH}_{4}{ }^{+}$was supplied, suggests that $\mathrm{N}$ rather than $\mathrm{C}$ of the DFAA controlled the urea uptake. In further support of a 'high quality' $\mathrm{N}$ control of urea utilization were the Limfjorden cultures, in which urea met 32 to $41 \%$ of the $\mathrm{N}$ demand when low amounts of $\mathrm{NH}_{4}^{+}$ $(<0.5 \mu \mathrm{M})$ and DFAA $(<240 \mathrm{nM})$ were present, but when $\mathrm{NH}_{4}{ }^{+}$was added the contribution was reduced to below $21 \%$. Contrasting these observations, no relations between urea uptake and concentrations of 'high quality' N was found in the Santa Rosa Sound. Despite low concentrations of $\mathrm{NH}_{4}{ }^{+}(<2 \mu \mathrm{M})$ and
DFAA $(<145 \mathrm{nM})$, no uptake of urea was measured although relatively high urea concentrations (0.8 to $0.9 \mu \mathrm{M})$ occurred. A similar lack of agreement between uptake of urea and availability of $\mathrm{NH}_{4}{ }^{+}$and DFAA was found in the Knebel Vig batch cultures. In these cultures the contribution of urea- $\mathrm{N}$ to the bacterial $\mathrm{N}$ demand ranged from 0.1 to $41 \%$, despite rather similar $\mathrm{NH}_{4}^{+}(0.2$ to $0.6 \mu \mathrm{M})$ and DFAA pools $(195 \pm 56 \mathrm{nM})$ occurred in all cultures.

Uptake of urea in the batch cultures enriched with different $\mathrm{C}$ and $\mathrm{N}$ sources showed that availability of a labile $\mathrm{C}$ source (glucose) and absence of a 'high quality' $\mathrm{N}$ source $\left(\mathrm{NH}_{4}{ }^{+}\right.$or DFAA) was a major controlling mechanism in stimulating the uptake of urea. As summarized in Fig. 8B, addition of glucose only led to an increased uptake of urea when $\mathrm{NH}_{4}{ }^{+}$was not present (Limfjorden and Santa Rosa Sound cultures). An additional effect of glucose addition was a stimulated 
uptake of DFAA, whether the cultures were enriched with $\mathrm{NH}_{4}{ }^{+}$or urea (Fig. 8B). The higher DFAA uptake most likely reflects the increase in bacterial biomass (Limfjorden cultures) or may indicate a stimulated uptake capacity for 'high quality' $\mathrm{N}$ to avoid utilization of urea.

\section{Urea uptake and bacterial $\mathbf{N}$ balance}

Uptake of urea, DFAA, $\mathrm{NH}_{4}{ }^{+}$and $\mathrm{NO}_{3}{ }^{-}$in most cases sustained a large portion or all of the bacterial $\mathrm{N}$ demand, but the significance of the different $\mathrm{N}$ sources varied. Without enrichment with $\mathrm{C}$ or $\mathrm{N}$, the $4 \mathrm{~N}$ sources sustained the following percentage of the bacterial $\mathrm{N}$ demand: urea 3 to $37 \%$, DFAA 21 to $100 \%$ (ignoring the $>100 \%$ values in the Roskilde Fjord cultures), $\mathrm{NH}_{4}{ }^{+} 5$ to $100 \%$ (ignoring the $>100 \%$ values in the Santa Rosa Sound cultures), and $\mathrm{NO}_{3}{ }^{-}-8$ (release) $-46 \%$ (Table 2 ). The dominant $\mathrm{N}$ source in Roskilde Fjord and Limfjorden was DFAA, while $\mathrm{NH}_{4}{ }^{+}$and $\mathrm{NO}_{3}{ }^{-}$were the major $\mathrm{N}$ sources in Knebel Vig. In Santa Rosa Sound, most of the bacterial $\mathrm{N}$ demand was supplied by $\mathrm{NH}_{4}{ }^{+}$.

DFAA and $\mathrm{NH}_{4}{ }^{+}$have previously been found to be major $\mathrm{N}$ sources for heterotrophic, aquatic bacteria (Hoch \& Kirchman 1995), but a significant bacterial uptake of urea in short-term studies has not been shown before. The in situ urea uptake in Roskilde Fjord is significantly above the maximum contribution of urea of $3 \%$ to the bacterial $\mathrm{N}$ demand observed in the Thames estuary (Middelburg \& Nieuwenhuize 2000). It is possible that higher DIN pools in the Thames estuary repressed the bacterial urea uptake.
Like urea, DFAA and $\mathrm{NH}_{4}{ }^{+}$contain $\mathrm{N}$ in a reduced form that can immediately enter biosynthetic processes. In contrast, reducing power $\left(\mathrm{NADH}^{+}\right.$or $\mathrm{NADPH}^{+}$) and hereby energy is required for the reduction of $\mathrm{NO}_{3}{ }^{-}$before the $\mathrm{N}$ moiety can be incorporated into bacterial biomass. The present finding of $\mathrm{NO}_{3}{ }^{-}$being an important bacterial $\mathrm{N}$ source agrees with observations of heterotrophic bacteria in North Atlantic waters in which $\mathrm{NO}_{3}{ }^{-}$met $20 \%$ or more of the $\mathrm{N}$ demand when $\mathrm{NO}_{3}{ }^{-}$exceeded $5 \mu \mathrm{M}$ (Allen et al. 2002, 2005). Possibly, the cost of reducing $\mathrm{NO}_{3}{ }^{-}$to $\mathrm{NH}_{4}{ }^{+}$is lower than the energy expenditure for producing urease and urea transport enzymes, and this may explain the urea uptake in the present studies. Opposite a reduction of $\mathrm{NO}_{3}^{-}$, in the Santa Rosa Sound cultures a production of $\mathrm{NO}_{3}{ }^{-}$was found. This production coincided with a high uptake of $\mathrm{NH}_{4}{ }^{+}$, and may reflect bacterial nitrification, but this was not studied.

Bacterial uptake of the different $\mathrm{N}$ compounds (urea, DFAA, $\mathrm{NH}_{4}{ }^{+}$and $\mathrm{NO}_{3}{ }^{-}$) sustained the entire $\mathrm{N}$ demand in some experiments, e.g. in 6 of the 9 Knebel Vig experiments, but only 67 to $78 \%$ in the remaining 3 experiments. Similarly, in the Limfjorden experiments, the $\mathrm{N}$ compounds only met $75 \%$ of the $\mathrm{N}$ demand in the urea- and glucose-enriched cultures. A potential $\mathrm{N}$ source that was not included in the present study are combined, e.g. protein-bound, amino acids, which are among the commonly utilized organic substrates by aquatic bacteria (Jørgensen et al. 1994, Keil \& Kirchman 1993). In support of this, an enhanced peptidase activity was measured in the Santa Rosa Sound cultures when $\mathrm{NH}_{4}{ }^{+}$was replaced by urea.

Table 2. Percentage contribution of $\mathrm{N}$ from uptake of urea, DFAA, ammonium and nitrate relative to the bacterial $\mathrm{N}$ biomass. All values are mean percentages. For the Roskilde Fjord field samples and the Knebel Vig batch cultures at Days 1, 5 and 9, mean values of the different sampling days and the measured ranges are shown. nd: not determined

\begin{tabular}{|c|c|c|c|c|c|}
\hline & & Urea & DFAA & Ammonium & Nitrate \\
\hline Roskilde Fjord Field samples & & $20(0.6-44)$ & $31(11-51)$ & nd & nd \\
\hline Roskilde Fjord Batch cultures & $\begin{array}{l}\text { Control } \\
+\mathrm{DFAA} \\
+\mathrm{NH}_{4}{ }^{+}\end{array}$ & $\begin{array}{c}3.3 \\
0.3 \\
1\end{array}$ & $\begin{array}{l}129 \\
220 \\
116\end{array}$ & $\begin{array}{l}\text { nd } \\
\text { nd } \\
\text { nd }\end{array}$ & $\begin{array}{l}\text { nd } \\
\text { nd } \\
\text { nd }\end{array}$ \\
\hline Knebel Vig Batch cultures & $\begin{array}{l}\text { Controls (Days 1-5-9) } \\
+\mathrm{N}+\mathrm{P}(\text { Days 1-5-9) } \\
+\mathrm{N}+\mathrm{P}+\mathrm{Si} \text { (Days 1-5-9) }\end{array}$ & $\begin{array}{c}29(10-54) \\
5(0.1-11) \\
15(0.1-33)\end{array}$ & $\begin{array}{l}27(27-28) \\
23(20-26) \\
21(13-26)\end{array}$ & $\begin{array}{l}37(6-60) \\
38(27-48) \\
42(30-55)\end{array}$ & $\begin{array}{l}46(9-97) \\
22(0.3-60) \\
29(1.8-61)\end{array}$ \\
\hline Limfjorden Batch cultures & $\begin{array}{l}\text { Control } \\
+ \text { Glucose } \\
+ \text { Glucose }+\mathrm{NH}_{4}^{+} \\
+ \text {Glucose }+\mathrm{NH}_{4}^{+}+\text {urea } \\
\text { +Glucose + urea }\end{array}$ & $\begin{array}{l}37 \\
44 \\
18 \\
19 \\
30\end{array}$ & $\begin{array}{l}69 \\
70 \\
61 \\
52 \\
45\end{array}$ & $\begin{array}{c}5 \\
9 \\
27 \\
18 \\
-0.7\end{array}$ & $\begin{array}{l}1.3 \\
0.5 \\
0.9 \\
0.8 \\
0.7\end{array}$ \\
\hline Gulf Breeze Batch cultures & $\begin{array}{l}\text { Control } \\
+ \text { Glucose }+\mathrm{NH}_{4}^{+} \\
+ \text {Glucose }+\mathrm{NH}_{4}^{+}+\text {urea } \\
+ \text { Glucose }+ \text { urea }\end{array}$ & $\begin{array}{c}-0.4 \\
-4 \\
-18 \\
81\end{array}$ & $\begin{array}{l}46 \\
24 \\
19 \\
35\end{array}$ & $\begin{array}{l}113 \\
98 \\
69 \\
60\end{array}$ & $\begin{array}{c}-8 \\
4 \\
0.2 \\
2\end{array}$ \\
\hline
\end{tabular}


In addition to uptake, a production of urea was observed in the Santa Rosa Sound cultures. Production of urea has previously been measured in bacterial batch cultures (Berman et al. 1999, Jørgensen et al. 1999a,b). The urea production may indicate a surplus of cellular $\mathrm{N}$ for biosynthesis, but it may also be caused by degradation of extracellular purines (Berman et al. 1999, Berg \& Jørgensen 2006, this issue).

Uptake of the different $\mathrm{N}$ compounds was related to the bacterial $\mathrm{N}$ production in the Roskilde Fjord and Santa Rosa Sound samples assuming a bacterial N content of $3.5 \mathrm{fg}$. This was based on a mean $\mathrm{N}$ content of bacteria from 6 aquatic locations (range was 1.6 to 5 fg) by Fagerbakke et al. (1996). The assumed $N$ content may have diverged from the actual bacterial $\mathrm{N}$ content in the cultures and may explain the calculated $\mathrm{N}$ contributions $>100 \%$. Using actual measurements of the bacterial $\mathrm{N}$ content, or a known $\mathrm{C}$ content and a C:N ratio of 5 (Table 1), contributions close to $100 \%$ to the bacterial $\mathrm{N}$ budgets by uptake of the different $\mathrm{N}$ compounds were obtained. Another potential source of error in the different $\mathrm{N}$ budgets may be the calculated incorporation of DFAA-N, which was based on net incorporation of $\left[{ }^{14} \mathrm{C}\right]-\mathrm{DFAA}$. To determine the total (gross) DFAA-N uptake, it was assumed that the incorporated DFAA-C represented $50 \%$ of the total DFAA uptake, i.e. $50 \%$ of the $\left[{ }^{14} \mathrm{C}\right]$-DFAA taken up were respired, while all $\mathrm{N}$ in the DFAA was incorporated into bacterial biomass. If the actual respiration percentage differed from $50 \%$ or if DFAA-N subsequently was released by the bacteria, the actual uptake of DFAA-N may have differed from the calculated values.

In addition to being a source of $\mathrm{N}$, some bacteria may also incorporate the $\mathrm{C}$ moiety of urea. In a study of urea uptake in soils, a minor incorporation of ${ }^{13} \mathrm{C}$ from ${ }^{13} \mathrm{C}$ urea was detected in phospholipid fatty acids in both heterotrophic and nitrifying bacteria (Petersen et al. 2004). It is uncertain if utilization of urea-C provides bacteria with nutritional advantages.

\section{Bacterial vs. community urea uptake}

Uptake of urea in the light in untreated Knebel Vig water was on average 15.8-fold higher than in the dark (if neglecting the extreme high 282-fold value of the $\mathrm{N}+\mathrm{P}+\mathrm{Si}$ mesocosms on Day 9). This shows that the major sink for urea in the shallow Knebel Vig bay was phytoplankton production. Dark uptake of urea by algal species has not been widely studied, but during dinoflagellate blooms a high urea uptake has been observed in the dark (Fan \& Glibert 2005, Kudela \& Cochlan 2000). Phototrophic flagellates dominated the phytoplankton community in the $\mathrm{N}+\mathrm{P}$ enclosures in
Knebel Vig (Baretta-Bekker et al. 1994), but urea uptake by the unidentified flagellates was not examined. In general, urea serves as an important supplementary $\mathrm{N}$ source to algae, especially when other $\mathrm{N}$ sources are depleted (Berman \& Bronk 2003). This is confirmed by summer algal blooms in the Baltic Sea (Tamminen \& Irmisch 1996).

In the Knebel Vig experiments, uptake of urea in the bacterial cultures receiving water from the mesocosms on Days 1, 5 and 9 corresponded to $158 \%$ (mean value; range was 8 to $450 \%$ ) of the community dark uptake in untreated water. A value of $100 \%$ would indicate that only bacteria took up urea in the dark. Due to methodological differences between the applied batch cultures (bacteria growing in $0.8 \mu \mathrm{m}$ filtered water for $42 \mathrm{~h}$ ) and intact, dark-incubated water samples, a difference in urea uptake rate would be anticipated. In the batch cultures, filtration through $0.8 \mu \mathrm{m}$ filters most likely removed some bacteria, and in the intact water, organic compounds from the stimulated phytoplankton production in the mesocosms may have favored specific microorganisms (Sundh 1992) and finally, algae may have taken up urea in the dark (Tamminen \& Irmisch 1996). However, considering these variables, the results indicate that bacteria accounted for a sizeable portion of the community dark uptake.

\section{CONCLUSIONS}

The studies on urea uptake in 4 estuarine environments demonstrated that natural bacterial populations are capable of utilizing urea as $\mathrm{N}$ source, but the uptake is variable. Manipulation of available $\mathrm{C}$ and $\mathrm{N}$ sources demonstrated a higher preference for $\mathrm{NH}_{4}{ }^{+}$ and amino acids than for urea, despite all compounds contain reduced $\mathrm{N}$. The mechanisms controlling utilization of urea by the bacteria seems to include a relatively slow uptake system for urea, energy expenditure for synthesis of urease and transport enzymes, and a limited number of bacteria possessing the urease enzyme. The observed uptake rates of urea, ranging from insignificant to sustaining about half of the bacterial $\mathrm{N}$ demand, indicate that prokaryotic urea utilization can be an important element in the global $\mathrm{N}$ cycling.

Acknowledgements. I thank R. E. Jensen for competent assistance during field and laboratory work, R. B. Coffin, Naval Research Laboratory, Washington, DC (previously Gulf Breeze Environmental Research Laboratory, Gulf Breeze, FL) and W. H. Jeffrey, Department of Biology, University of West Florida, Pensacola, FL, for providing laboratory facilities for parts of the experimental work, and N. Kroer, National Environmental Research Laboratory, Roskilde, Denmark, for assis- 
tance during field work in Denmark. Financial support was provided by the National Danish Strategic Environmental Research Program and the Danish Natural Science Research Council.

\section{LITERATURE CITED}

Allen AE, Howard-Jones MH, Booth MG, Frischer ME, Verity PG, Bronk DA, Sanderson MP (2002) Importance of heterotrophic bacterial assimilation of ammonium and nitrate in the Barents Sea during summer. J Mar Syst 38: 93-108

Allen AE, Booth MG, Verity PG, Frischer ME (2005) Influence of nitrate availability on the distribution and abundance of heterotrophic bacterial nitrate assimilation genes in the Barents Sea during summer. Aquat Microb Ecol 39: $247-255$

Antia NJ, Harrison PJ, Oliveira L (1991) The role of dissolved organic nitrogen in phytoplankton nutrition, cell biology and ecology. Phycologia 30:1-89

Ayo B, Unanue M, Azua I, Gorsky G, Turley C, Iriberri J (2001) Kinetics of glucose and amino acid uptake by attached and free-living marine bacteria in oligotrophic waters. Mar Biol 138:1071-1076

Baretta-Bekker JG, Riemann B, Baretta JW, Rasmussen EK (1994) Testing the microbial loop concept by comparing mesocosm data with results from a dynamical simulationmodel. Mar Ecol Prog Ser 106:187-198

Beckers G, Bendt AK, Krämer R, Burkovski A (2005) Molecular identification of the urea uptake system and transcriptional analysis of urea transporter and urease-encoding genes in Corynebacterium glutamicum. J Bacteriol 186: 7645-7652

Berg GM, Jørgensen NOG (2006) Purine and pyrimidine metabolism by estuarine bacteria. Aquat Microb Ecol 42:215-226 (this issue)

Berman T, Bronk DA (2003) Dissolved organic nitrogen: a dynamic participant in aquatic ecosystems. Aquat Microb Ecol 31:279-305

Berman T, Bechemin C, Maestrini SY (1999) Release of ammonium and urea from dissolved organic nitrogen in aquatic ecosystems. Aquat Microb Ecol 16:295-302

Bronk DA (2002) Dynamics of DON. In: Hansell DA, Carlson CA (eds) Biogeochemistry of marine dissolved organic matter. Academic Press, Amsterdam, p 153-249

Cho BC, Park MG, Shim JH, Azam F (1996) Significance of bacteria in urea dynamics in coastal surface waters. Mar Ecol Prog Ser 142:19-26

Conover RJ, Gustavson KR (1999) Sources of urea in arctic seas: zooplankton metabolism. Mar Ecol Prog Ser 179: 41-54

Fagerbakke KM, Heldal M, Norland S (1996) Content of carbon, nitrogen, oxygen, sulfur and phosphorus in native aquatic and cultured bacteria. Aquat Microb Ecol 10:15-27

Fan CL, Glibert PM (2005) Effects of light on nitrogen and carbon uptake during a Prorocentrum minimum bloom. Harmful Algae 4:629-641

Friedrich B, Magasanik B (1977) Urease of Klebsiella aerogenes-Control of its synthesis by glutamine-synthetase. J Bacteriol 131:446-452

Fuhrman J (1990) Dissolved free amino acid cycling in an estuarine outflow plume. Mar Ecol Prog Ser 66:197-203

Fuhrman JA, Azam F (1980) Bacterioplankton secondary production estimates for coastal waters of British Columbia, Antarctica, and California. Appl Environ Microbiol 39: 1085-1095
Glibert PM, Corley DJ, Fisher TR, Harding LW Jr, Malone TC (1995) Dynamics of the 1990 winter/spring bloom in Chesapeake Bay. Mar Ecol Prog Ser 122:27-43

Glibert PM, Trice TM, Michael B, Lane L (2005) Urea in the tributaries of the Chesapeake and coastal bays of Maryland. Water Air Soil Pollut 160:229-243

Hobbie JE, Daley RJ, Jasper S (1977) Use of nucleopore filters for counting bacteria by fluorescence microscopy. Appl Environ Microbiol 33:1225-1228

Hoch MP, Kirchman DL (1995) Ammonium uptake by heterotrophic bacteria in the Delaware estuary and adjacent coastal waters. Limnol Oceanogr 40:886-897

Jahns T (1992) Regulation of urea uptake in Pseudomonas aeruginosa. Antonie Leeuwenhoek 62:173-179

Jespersen AM, Christoffersen K (1987) Measurements of chlorophyll-a from phytoplankton using ethanol as extraction solvent. Arch Hydrobiol 109:445-454

Jørgensen NOG (1987) Free amino acids in lakes. Concentrations and assimilation rates in relation to phytoplankton and bacterial production. Limnol Oceanogr 32:97-111

Jørgensen NOG, Kroer N, Coffin RB, Yang XH, Lee C (1993) Dissolved free amino acids, combined amino acids, and DNA as sources of carbon and nitrogen to marine bacteria. Mar Ecol Prog Ser 98:135-148

Jørgensen NOG, Kroer N, Coffin RB (1994) Utilization of dissolved nitrogen by heterotrophic bacterioplankton: Effect of substrate C/N ratio. Appl Environ Microbiol 60: 4124-4133

Jørgensen NOG, Tranvik L, Edling H, Graneli W, Lindell M (1998) Effects of sunlight on occurrence and bacterial turnover of specific carbon and nitrogen compounds in lake water. FEMS Microbiol Ecol 25:217-227

Jørgensen NOG, Kroer N, Coffin RB, Hoch MP (1999a) Relations between bacterial nitrogen metabolism and growth efficiency in an estuarine and an open-water ecosystem. Aquat Microb Ecol 18:247-261

Jørgensen NOG, Tranvik LJ, Berg GM (1999b) Occurrence and bacterial cycling of dissolved nitrogen in the Gulf of Riga, the Baltic Sea. Mar Ecol Prog Ser 191:1-18

Keil RG, Kirchman DL (1991) Contribution of dissolved free amino acids and ammonium to the nitrogen requirements of heterotrophic bacterioplankton. Mar Ecol Prog Ser 73: $1-10$

Keil RG, Kirchman DL (1993) Dissolved combined amino acids: Chemical form and utilization by marine bacteria. Limnol Oceanogr 38:1256-1270

Kirchman DL (2000) Uptake and regeneration of inorganic nutrients by marine heterotrophic bacteria. In: Kirchman DL (ed) Microbial ecology of the oceans. John Wiley \& Sons, London, p 261-288

Kroer N (1993) Bacterial growth efficiency on natural dissolved organic matter. Limnol Oceanogr 38:1282-1290

Kroer N (1994) Relationships between biovolume and carbon and nitrogen content of bacterioplankton. FEMS Microbiol Ecol 13:217-223

Kudela RM, Cochlan, WP (2000) Nitrogen and carbon uptake kinetics and the influence of irradiance for a red tide bloom off southern California. Aquat Microb Ecol 21: 31-47

Lindroth P, Mopper K (1979) High performance liquid chromatographic determination of subpicomole amounts of amino acids by precolumn fluorescence derivatization with o-phthaldialdehyde. Anal Chem 51:1667-1674

Lomas MW, Trice TM, Glibert PM, Bronk DA, McCarthy JJ (2002) Temporal and spatial dynamics of urea uptake and regeneration rates and concentrations in Chesapeake Bay. Estuaries 25:469-482 
Lomstein BAa, Blackburn H, Henriksen K (1989) Aspects of nitrogen and carbon cycling in the northern Bering Shelf sediment: I. The significance of urea turnover in the mineralization of $\mathrm{NH}_{4}{ }^{+}$. Mar Ecol Prog Ser 57:237-247

Madigan MT, Martinko JM, Parker J (2003) BROCK Biology of microorganisms, 10th edn. Prentice Hall, Upper Saddle River, NJ

Middelboe M, Kroer N, Jørgensen NOG, Pakulski D (1998) Influence of sediment on pelagic carbon and nitrogen turnover in a shallow Danish estuary. Aquat Microb Ecol 14:81-90

Middelburg JJ, Nieuwenhuize J (2000) Nitrogen uptake by heterotrophic bacteria and phytoplankton in the nitraterich Thames estuary. Mar Ecol Prog Ser 203:13-21

Mobley HLT, Island MD, Hausinger RP (1995) Molecular biology of microbial ureases. Microbiol Rev 59:451-480

Mulvaney RL, Bremer JM (1979) A modified diacetyl monoxime method for colorimetric determination of urea in soil extracts. Commun Soil Sci Plant Anal 10: $1163-1170$

Pedersen H, Lomstein BAa, Blackburn TH (1993) Evidence for bacterial urea production in marine sediments. FEMS Microbiol Ecol 12:51-59

Petersen SO, Roslev P, Roland B (2004) Dynamics of a pasture soil microbial community after deposition of cattle urine amended with $\left[{ }^{13} \mathrm{C}\right]$ urea. Appl Environ Microbiol 70 : 6363-6369

Price NM, Harrison PJ (1987) Comparison of methods for the

Editorial responsibility: Frede Thingstad,

Bergen, Norway analysis of dissolved urea in seawater. Mar Biol 94: 307-317

Riemann B, Bell RT, Jørgensen NOG (1990) Incorporation of thymidine, adenine and leucine into natural bacterial assemblages. Mar Ecol Prog Ser 65:87-94

Sahlsten E, Sörensen F, Petterson K (1988) Planktonic nitrogen uptake in the south-eastern Kattegat. J Exp Mar Biol Ecol 121:227-246

Siewe RM, Weil B, Burkovski A, Eggeling L, Kramer R, Jahns $\mathrm{T}$ (1998) Urea uptake and urease activity in Corynebacterium glutamicum. Arch Microbiol 169:411-416

Simon M, Azam F (1989) Protein content and protein syntesis rates of planktonic marine bacteria. Mar Ecol Prog Ser 51: 201-213

Sundh I (1992) Biochemical composition of dissolved organic carbon released from natural communities of lake phytoplankton. Arch Hydrobiol 125:347-369

Tamminen T, Irmisch A (1996) Urea uptake kinetics of a midsummer planktonic community on the SW coast of Finland. Mar Ecol Prog Ser 130:201-211

Therkildsen MS, Lomstein BAa (1994) Seasonal variation in sediment urea turnover in a shallow estuary. Mar Ecol Prog Ser 109:77-82

Vogels GD, van der Drift C (1976) Degradation of purines and pyrimidines by microorganisms. Bacteriol Rev 40:403-468

Wheeler PA, Kirchman DL (1986) Utilization of inorganic and organic nitrogen by bacteria in marine systems. Limnol Oceanogr 31:998-1009

Submitted: August 25, 2005; Accepted: November 21, 2005

Proofs received from author(s): March 6, 2006 